\title{
МОНОГОРОДА В СИСТЕМЕ МОДЕРНИЗАЦИИ ЭКОНОМИКИ РЕГИОНА
}

\author{
(c) 2018 Карпичев Евгений Владимирович
}

кафедра экономики и управления предприятиями и производственными комплексами

Санкт-Петербургский государственный экономический университет

191023, Санкт-Петербург, Садовая ул., д.21,

E-mail:kev@szfo.gov.ru

В статье анализируются подходы к решению проблем модернизации экономики. Рассматривается соотношение понятий «модернизация» и «индустриализация». Особое внимание уделяется роли и месту модернизации моногородов в экономике регионов. Показана необходимость и направления модернизации экономики Северо-Западного Федерального округа на основе реиндустриализации моногородов.

Ключевые слова: модернизация, регион, моногорода, реиндустриализация.

Традиционно, преимущественно в западных теориях, модернизация представляется как процесс преобразования сложившихся обществ, находящихся на низком уровне развития, к современному обществу. При этом под современным обществом, как мы увидим далее, понимается западное общество в различных его аспектах: экономическом, социальном духовном. Так, один из главных сторонников этой теории модернизации С. Айзенштадт утверждает, что «Исторически, модернизация - процесс изменения (движения) к тем типам социальных, экономических, и политических систем, которые развивались в Западной Европе и Северной Америке с семнадцатого столетия к девятнадцатому, и распространились на другие европейские страны, в девятнадцатых и двадцатых веках в Южной Америке, Азии и африканском континенте» [1].

При этом, основное внимание теория модернизации уделяет путям, в результате продвижения по которым так называемые традиционные общества становятся современными (т.е., ориентированными на Запад) за счет процессов экономического роста и изменения в социальных, политических, и культурных структурах.

Вообще понятию «модернизация» в западной литературе давался ряд толкований с различных точек зрения наряду с ее оригинальным значением. Так, ряд ученых трактовал это понятие как «процесс социальных изменений» [2, 3, 4] (Huntington S, 1968, Finkele J. 1969, Lerner D. 1958), другие же ученые, например M. Halpern [5], рассматривают модернизацию не только как изменение, но также и как ответ (реакцию), т.е. способность учреждений эффективно управлять изменениями.

Комбинируя эти два представления, С. Айзенштадт (1966) [1] представляет модернизацию как процесс изменений, подчеркивая необходимость способности самих учреждений управлять им или же приспособиться к таким изменениям. Точно так же В.В. Ростоу представил модель, которую рассматривают как проект подхода к модернизации, состоящую из серии стадий, таких как стадия классового (традиционного) общества, переходное общество, стадия «разбега» (сдвига), затем «зрелости» и, наконец, эра массового потребления [6].

Практически всеми исследователями особое место в процессе модернизации уделяется проблеме индустриализации, в контексте экономического роста. При этом нужно отметить, что термины модернизация, индустриализация, и развитие часто используются попеременно, но фактически обращаются к различимым явлениям. Индустриализация - более узкий термин чем модернизация, в то время как развитие является более общим понятием. Индустриализация, по мнению теоретиков, способствует расширению использования материальных факторов, в частности в форме автоматизации и роботизации производства, ч.; то влечет за собой рост производства, занятости (даже при снижении трудоемкости основных бизнес-процессов), заработной платы, дохода и возможностей для профессионального разнообразия. Индустриализация в широком смысле этого понятия, может отсутствовать при наличии политической, социальной, или культурной модернизации, и, наоборот, может существовать в отсутствие других аспектов модернизации. 
Если говорить о модернизации, в российском понимании, в широком смысле слова, то, к сожалению, методические подходы к этому явлению настолько различны, что свести их воедино достаточно сложно. Ряд работ действительно посвящен традиционному, принятому в западной интерпретации, определению модернизации и соответствующей трактовке ее составляющих (экономическая, политическая, социальная, культурная) [7, 8, 9]. Достаточно много работ, посвящённых экономической модернизации России, появилось после провозглашенного в 2008 году Президентом Российской Федерации Д. Медведевым курса на модернизацию российской экономики, причем интенсивность их появления заметно снижалась по мере провозглашения новых приоритетных направлений развития.

Все эти исследования, как правило, посвящены проблемам модернизации региональных экономик (на уровне субъектов федерации) $[11,12,13]$, решению проблем территориального управления в условиях модернизации экономик и др. Из имеющихся в этом направлении работ, наверное, стоило бы отметить труды таких авторов как А.Г. Полякова [14], Ищенко-Падукова О.А. и Мовчан И.А. [15], другие. В то же время практически отсутствуют исследования, связанные с модернизацией структур более высокого порядка, в частности, федеральных округов. В тоже время в современных условиях федеральный округ представляется как макрорегион, в рамках которого можно говорить об модернизационных процессах.

В российском понимании, понятие «модернизация» экономики, связанно с понятием «индустриализация» и, как правило, означает обновление, преодоление отсталости, достижение современного, сравнимого с передовыми странами уровня развития, что достигается за счет следующих мероприятий:

- освоение и реализация производства современной инновационной продукции, дающей возможность не просто выхода на зарубежные рынки, но и завоевания на них соответствующих позиций;

- коренное обновление производственного аппарата промышленных предприятий на основе замены устаревшего оборудования на высокотехнологичное и более производительное;

- включение в мировые инновационные процессы, дальнейшая интеграция в мировую экономику, ускорение использования результатов инновационной деятельности других субъектов хозяйствования, в том числе организационно-экономических инноваций;

- постоянное повышение квалификации персонала, в первую очередь, в отраслях определяющих направленность и темпы научно-технического прогресса, переподготовка высвобождающегося в результате автоматизации и роботизации персонала, изменение структуры подготовки кадров в учебных заведения с акцентом на опережающее обучение и др.;

- реализация структурных сдвигов в экономике, формирование производственной структуры, отвечающей критериям развитой индустриальной страны, что предполагает повышение доли в ВВП и экспорте продуктов с высокой добавленной стоимостью, в том числе продуктов новой цифровой экономики.

Нужно отметить, что проблема модернизации непосредственно связана с объектом модернизации - район или муниципальное образование, экономически обособленный регион или субъект федерации, макрорегион или федеральный округ. «Границы субъектов федерации и экономически обособленных регионов не всегда совпадают. Отметим, что в современных условиях регион представляет собой автономный сектор экономики с устойчивыми внутренними финансово-экономическими связями, активно конкурирующий и сотрудничающий с другими регионами. С этой точки зрения возникает вопрос об идентификации сущности крупных агломераций, которые представляют собой единое социально-экономическое пространство, и выступают в качестве экономического региона» [16].

Агломерационные процессы, которые в соответствии с вышеизложенными теориями, объективно отражают сложившиеся и формирующиеся социально-экономические связи регионов, охватывают в настоящее время Санкт-Петербург и Ленинградскую область и частично Новгородскую и Псковские области, т.е. весь Северо-Западный экономический район.

Кроме того, развитие Северного и Северо-Западного экономических районов с момента резкого усиления сырьевых отраслей в структуре хозяйства северных областей, и в последующем повлекшее пересмотр парадигмы их развития, сформировало в середине XX века устойчивые экономические и транспортно-логистические 
связи, сохранившиеся в постсоветский период и ускоренно развивающиеся в настоящее время.

Ключевыми факторами формирования единого экономического макрорегиона на северо-западе Российской Федерации стали развитие новых транспортных коридоров Россия-Скандинавия и Россия-Западная Европа, а также инновационное развитие логистических схем транспортировки природного газа и нефти.

Реализация таких проектов как Балтийская трубопроводная система, «Северный поток» и «Северный поток-2», возведение мощностей по производству СПГ в Усть-Луге для обеспечения транспортировки газа, добываемого на Северо-Западе РФ, морским путем, а также текущие проекты освоения Арктики, материальная, технологическая и научная база которых в основном формируется компаниями и институтами Санкт-Петербурга и других регионов Северо-Запада, предопределяют как удовлетворение потребностей макрорегиона, так и наращивание его экспорта в Европейские страны.

Нужно отметить, что проблемы модернизации экономики Северо-Западного федерального округа в различных аспектах неоднократно рассматривались такими учеными как М.А. Лапочкина, Шабунова А, А., Кузнецова С.В. и рядом других авторов [17-20].

Особое место в решении проблемы модернизации экономики федеральных округов занимает проблема реиндустриализации моногородов. Сущность моногорода раскрывается в ряде определений, однако смысл состоит в том, что он представляет собой населенный пункт (муниципальное образование) с монопрофильной структурой экономики, связанной с предприятием или группой тесно интегрированных между собой предприятий единой отраслевой направленности.

Генезис моногородов произрастает из принципов советской экономики, основывавшихся на предприятиях гигантах и тезиса эффективности роста масштаба на основе концентрации производства. Особенностью таких населенных пунктов является их не то, чтобы изоляция, а плановое размещение, как правило, вдали от крупных населенных пунктов, хотя были и другие варианты. В условиях директивной экономики подобные процессы поддерживались государством, которое интересовало повышение народнохозяйственной эффективности производства, а финансирование предприятий осу- ществлялось централизованно, вне оценки локальной эффективности.

При переходе к рыночной экономике и приватизации большей части промышленных предприятий, изменился принцип оценки эффективности их деятельности и на первое место вышел показатель их прибыли. Естественно, что собственник начинал избавляться от непрофильных активов, к которым относились, в первую очередь, объекты социальной инфраструктуры, здравоохранения и др. и передавать их в управление муниципальным образования, что в условиях дефицита средств приводило к их угасанию и, в конечном итоге, ликвидации.

Проблеме моногородов, хотя и уделялось значительное внимание и в условиях перехода России к рыночной экономике, однако, несмотря на значительное количество нормативных актов, декларирование мер поддержки структурообразующих предприятий, проблема решена не была. Сейчас вновь возникает вопрос, что делать с подобными населёнными пунктами, основу которых составляет единственное предприятие, и какова перспектива населения этих городов.

Основная сложность состоит в том, что при ликвидации или в условиях значительного снижения объема производства таких предприятии, собственник в целях снижения затрат, в первую очередь, смотрит в сторону уменьшения численности работающих на предприятии. Последнее закономерно приводит к увольнению работников, что в условиях отсутствия в небольшом городе мест трудоустройства ведет к росту безработицы, снижению доходов населения и ухудшению социального климата. Тем не менее, в последнее время государство усилило поддержку предприятий, которые являются значимыми для жизни всего города, однако, недостаточно определена роль государственных органов управления на региональном и муниципальном уровнях и по-прежнему отсутствует четкий алгоритм их действий.

В 1991 году моногорода составляли почти 40\% всех городов страны, где проживало 23\% городского населения. Уже в конце 1990-х годов к моногородам относилось $14 \%$ российских городов, где проживало 12\% городского населения страны [21]. Распоряжением Правительства Российской Федерации от 29.07.2014 N1398-р (ред. от 24.11.2015) «Об утверждении перечня моногородов» утверждён список моногородов 
Российской Федерации, включающий на 24 ноября 2015 года 319 муниципальных образований, где по состоянию на начало 2016 г. проживало 13 млн. человек (около 9\% населения России) [22]. Моногорода были распределены на данный период на три категории в зависимости от степени ухудшения складывающейся в них социально-экономической ситуации:

- моногорода с наиболее сложным социально-экономическим положением (94 моногорода);

- моногорода, имеющие риски ухудшения социально-экономического положения (154 моногорода);

- моногорода со стабильной социально-экономической ситуацией (71 моногород) [23].

Не вдаваясь в подробности рассмотрим состояние и перспективы реиндустриализации моногородов Северо-Западного федерального округа (СЗФО). Северо-Западный федеральный округ занимает 9,9\% территории России, в его составе 11 субъектов Российской Федерации, включая город федерального значения Санкт-Петербург. В СЗФО на 1 января 2018 г. проживает 13,9 млн. человек (9,5\% населения страны), из них городские жители составляют 84,4\%.

Доля экономически активного населения в округе $-71,1 \%$ (по России $-68,3 \%$ ). Тем не менее, происходит снижение доли населения в трудоспособном возрасте в регионах, относящихся к Европейскому Северу (Республика Карелия, Республика Коми, Архангельская и Мурманская области), идет миграционный отток населения. К числу ряда потенциальных преимуществ СЗФО можно отнести следующие:

- географическое положение, определяемое соседством со странами СНГ и ЕС и выходом к морским торговым путям;

- наличие структурообразующего центра СЗФО - Санкт-Петербурга - научного-образовательного и культурного центр округа, крупнейшего центра внешнеэкономических связей России и промышленного производства;

- округ богат природными ресурсами - лес, цветные металлы и апатиты, железо, нефть и газ при достаточно (на среднероссийском уровне) развитой производственной инфраструктуре.

Регионы СЗФО отличаются неравномерностью социально- экономического развития. ВРП на душу населения в Псковской области в три раза меньше, чем в Коми, а в половине регионов (Карелия, Вологодская, Калининградская, Нов- городская и Псковская области) данный показатель меньше, чем в среднем по России. Лидирует в развитии город Санкт-Петербург, который обеспечивает почти 48\% ВРП округа [24].

С одной стороны, важнейшей функцией округа является обеспечение внешнеэкономических связей России с Европейским союзом, что определило развитие транспортной инфраструктуры и трансграничного сотрудничества, ориентацию значительной части бизнеса на обслуживание внешнеэкономических связей. Возросла роль СЗФО в освоении арктических территорий.

Важным преимуществом округа является культурно-исторический потенциал, способствующий повышению привлекательности территории для населения, туристов и инвесторов.

Практически для всех регионов округа наиболее значимыми остаются проблемы социально-экономического развития муниципальных образований, в первую очередь, в сельской местности. Наиболее серьезные связаны с оттоком населения в крупные города, сокращением объектов отраслей лесного комплекса и сельского хозяйства, социальной инфраструктуры. Все это в какой-то степени является следствием падения уровня и качества жизни в моногородах. На территории Северо-Западного федерального округа насчитывается 41 моногород, 17 из которых признаны Правительством Российской Федерации муниципальными образованиями с наиболее сложным социально-экономическим положением.

В 2014 году принят Федеральный закон № 473-Ф3 [25] о создании территорий опережающего социально-экономического развития в ряде городов страны. Указанное решение принято в целях повышения привлекательности моногородов для внешних инвесторов и к настоящему времени в СЗФО сформировано уже 8 таких территорий (2 такие территории расположены в Республике Карелия и по одной - в шести других регионах округа).

Вообще, предполагалось, что в ближайшие два года в российских моногородах будет создано 230 тысяч новых рабочих мест и привлечено до 170 миллиардов рублей инвестиций [26]. А преференциальные территории, созданные в рамках таких муниципальных образований, позволят диверсифицировать экономику, привлечь инвестиций и создать новые рабочие места, не связанные с деятельностью градо- 
образующей организации. Однако по состоянию на август 2018 года резидентами всех территорий опережающего социально-экономического развития, созданных в субъектах Российской Федерации, являются только 158 предприятий. В СЗФО во всех действующих восьми таких территориях зарегистрировано только 12 резидентов, из которых 5 - в Кировске (Мурманская область), и 3 - в Череповце (Вологодская область).

Таким образом, единого алгоритма вывода социально-экономической ситуации в моногородах на траекторию устойчиво развития пока еще не разработано и здесь проблема состоит в том, что сами моногорода являются частью социально-экономических систем более высокого порядка - субъектов федерации и федеральных округов, что требует придания функции их координации органам управления федеральными округами.

\section{Библиогафический список}

1. Eisenstadt S.N. Modernization: Protest and Change. Englewood Cliffs: Prentice-Hall, 1966.

2. Huntington. Political order in changing societies, New Haven and London, Yale university press. 1968;

3. Finklc J.L., Gable R W. (eds.). Political Development and Social Change. N.Y.. London, Sydney, 1966.;

4. Lerner $D$. The Passing of Traditional Society: Modernizing the Middle East. New York, London. 1965

5. Halpern Manfred. The Revolution of Modernization in National and International Society. 1966. Pp. 178-214 in Friedrich. Carl J. (ed.). Revolution. New York: Atherton Press

6. Rostow W. W. The Stages of Economic Growth. ANon-Communist Manifesto. Cambridge, 1960; Rostow W. W. Politics and the Stages of Growth. Cambridge, 1971.

7. Гавров С.Н. Модернизация России: постимперский транзит М.: МГУДТ, 2010.269 с;

8. Канарш Г.Ю. Опыт и уроки советской модернизации. Часть I // Информационный гуманитарный портал «Знание. Понимание. Умение». 2016. № 2 (март - апрель).;

9. Канарш Г.Ю. Опыт и уроки советской модернизации. Часть II // Информационный гуманитарный портал «Знание. Понимание. Умение». 2016. № 3 (май - июнь).

10. Медведев назвал 10 направлений модернизации экономики России. 26.01.2011. http://www. iarcx.ru/ news/12208.html

11. Кузнецов С.И.. Межевич Н.М., Лачининский С.С. Пространственное развитие: роль внешнеэкономических вызовов в модернизации на Северо-Западе России. Санкт-Петербург. 2016.

12. Ласточкина М.А. Территориальные особенности модернизации России //Региональная экономика и управление. Электронный журнал. 2013. № 2 (34).

13. Калужский М.Л. Перспективы реформирования регионального экономического управления в Российской Федерации на современном этапе / Социально-экономические проблемы развития рыночной экономики: Сб. науч. тр.,- Омск: ОмГТУ. 2009.- С. 80-93.

14. Полякова А.Г. Концептуальные основы модернизации экономики регионов. hllp:/sun.tsu.ru/ mminfo/000063105/323/image/323-273.pdf

15. Ищенко-Падукова О.А., Мовчан И.А. Модернизация институтов региональной промышленной политики Юга России в условиях глобализации // Вестник науки и образования.- http://scientificjournal.ru/2-ozhurnale-vcslnik-nauki-i-obrazovaniya/I32-inodemizatsiya-iustilulov-rcgionalnoj-ekonomicheskoj-politiki2. html

16. Ксенофонтов В.И. Теоретико-методологические основы управления сбалансированным развитием региона. диссертация ... доктора экономических наук: 08.00 .05 / Ксенофонтов Виталий Иванович; Ин-т проблем региональной экономики РАН. Санкт-Петербург, 2011. 348 с

17. Лапочкина М.А. Территориальные особенности модернизации России // Региональная экономика и управление. Электронный научный журнал.2013. № 2 (34).

18. Шабунова А.А., Гулин К.А., Ласточкина М.А., Соловьева Т.С. Модернизация экономики региона: социокультурные аспекты.- Вологда. 2012. 158 с.

19. Ласточкина М.А.. Шабунова А.А. Возможности и ограничения модернизационного развития регионов Северо-Западного федерального округа // Экономические и социальные перемены: факты, тенденции, прогноз. 2013. № 5 (29).

20. Кузнецов С.В.. Горин Е.А. Устойчивое развитие регионов и модернизация научно- производственного комплекса Северо-Запада России//Экономика и управление. 2018. № 1 (147).

21. Развитие моногородов России: монография / колл. авт. Под ред. д-ра экон. наук, проф. И.Н. Ильиной. М.: Финансовый университет. 2013.168 с. 
22. Обзор российских моногородов. Аналитический доклад Института комплексных стратегических исследований (ИКСИ), Июнь 2017 г.с. 1

23. https://ru.wikipedia.org/wiki/Градообразующее_предприятие.

24. Россия в цифрах. Краткий статистический сборник.- М.:2018.

25. Федеральный закон от 29 декабря 2014 г. № 473-Ф3 «О территориях опережающего социально- экономического развития в Российской Федерации».

26. Без приставки «Моно». 22 марта 2017 года. http://моногорода.pф/news/23

Поступила в редакцию 09.09.2018 